\title{
A novel quantitative mating assay for the fungal pathogen Cryptococcus neoformans provides insight into signalling pathways responding to nutrients and temperature
}

\author{
Hui Dong and William Courchesne
}

Author for correspondence: William Courchesne. Tel: +1 702784 4113. Fax: +1 7027841620 . e-mail: wec@med.unr.edu

Department of Microbiology, School of Medicine, University of Nevada, Reno, NV 89557-0046, USA

\begin{abstract}
Cryptococcus neoformans is a fungal pathogen that causes a lethal meningitis in immunocompromised individuals. Several factors are associated with virulence of this fungus, including its mating type; however, the mechanism by which mating type affects virulence is unknown. $C$. neoformans is a basidiomycete that exists in two mating types called a and $\alpha$ that can fuse to form an a/ $\alpha$ dikaryon. A mating assay was developed that allowed a quantitative analysis of cryptococcal mating physiology. Interestingly, the efficiency of mating appeared to be dependent on temperature, being highest at $30^{\circ} \mathrm{C}$ and almost completely absent at $37^{\circ} \mathrm{C}$. Thus, while mating type itself may be associated with virulence (which must occur at $37^{\circ} \mathrm{C}$ ), the ability to mate is probably not a virulence factor. Mating efficiency was increased by altering the carbon or nitrogen sources to give so-called starvation media. The addition of various drugs also seemed to alter the frequency of mating, depending on the composition of mating medium. The data suggested that CAMP, 8-bromo-CAMP and caffeine increased mating on starvation medium but only CAMP and 8-bromo-cAMP stimulated mating on rich medium; caffeine was unable to stimulate mating on rich medium. Aluminium fluoride, an activator of heterotrimeric GTP-binding proteins (G-proteins), was also found to stimulate mating, suggesting the involvement of a G-protein that may regulate the level of CAMP.
\end{abstract}

Keywords: Cryptococcus neoformans, mating, virulence, signalling

\section{INTRODUCTION}

Cryptococcus neoformans is an opportunistic yeast pathogen that infects individuals with a compromised immune system, such as those with AIDS or those undergoing cancer chemotherapy (Kwon-Chung \& Bennett, 1992; Mitchell \& Perfect, 1995; Sugar, 1991). The most common infection caused by this yeast is a lethal meningitis (Chuck \& Sande, 1989; Kovacs et al., 1985; Rozenbaum \& Rios Goncalves, 1994; Stansell, 1993; Zuger et al., 1986). Several virulence factors have been found for $C$. neoformans, including the mating type of the cells. In particular, $\alpha$ cells have been reported to be more virulent than a cells (Kwon-Chung et al.,

Abbreviations: 8-Br-CAMP, 8-bromo-cyclic adenosine monophosphate; 5-FOA, 5-fluoroorotic acid.
1992). However, the mechanism underlying the association of virulence with mating type is not known.

The molecular mechanisms of mating are best understood for the pheromone-response pathways in the yeasts Saccharomyces cerevisiae and Schizosaccharomyces pombe (for reviews see Blumer \& Thorner, 1991; Kurjan, 1993; Marsh et al., 1991; Nielsen, 1993; Sprague \& Thorner, 1992). There is also evidence suggesting that many basidiomycetes, including Cryptococcus, have similar pheromone-response pathways (for a review see Vaillancourt \& Raper, 1996). C. neoformans is a haploid fungus that grows by vegetative budding. The haploid cells have two mating types, $a$ and $\alpha$. When a cells and $\alpha$ cells are co-cultured on a suitable medium, mating occurs, resulting in a morphological change, cell-cell fusion and formation of a dikaryon (Kwon-Chung, 1976a, b). The dikaryon undergoes mitotic divisions and polarized growth to form hyphae in which the haploid 
nuclei fuse and undergo meiosis. In addition, a putative pheromone gene has been found within the $\alpha$ mating type locus (Moore \& Edman, 1993) and a gene, GPA1, encoding the $\alpha$ subunit of a G-protein homologous to that involved in mating in yeast, has been identified (Tolkacheva et al., 1994). Although there has been characterization of hyphae and basidiospore formation, little is known about the initiation of the mating process.

Mating studies in Sacch. cerevisiae have benefited from the existence of a quantitative assay for mating, which relies on the ability of the product of mating, a diploid cell, to grow vegetatively, thus allowing its selection by complementation of auxotrophic markers. The mating product for Cryptococcus, the dikaryotic cell, has not been shown to grow vegetatively nor to form colonies, making the Sacch. cerevisiae assay unusable. Thus, a novel assay was developed in an attempt to quantitate mating of cryptococcal cells. This quantitative assay, described here, was used to show that the efficiency of mating was affected by the carbon and nitrogen sources, temperature, and several drugs, providing insight into the signalling pathways controlling this process.

\section{METHODS}

Strains and media. The strains used in this study (kindly provided by J. Edman, University of California, San Francisco, CA, USA) were JEC43 (mating type $\alpha$, ura5), JEC50 (mating type $\alpha$, ade2) and JEC61 (mating type a, ade2). These strains are isogenic except for the indicated genotypes.

Cells were grown in liquid SD (synthetic medium, with dextrose) in preparation for mating. SD contained $0.17 \%$ $(w / v)$ Difco yeast nitrogen base without amino acids and ammonium sulfate, $0.4 \%(\mathrm{w} / \mathrm{v})$ ammonium sulfate and $2 \%$ $(w / v)$ glucose. Matings of cryptococcal cells were done on four agar media: SD, SD $\Delta \mathrm{N}$, SS or $\mathrm{SS} \Delta \mathrm{N}$. SD agar was identical to SD liquid, with the addition of Bacto-agar $(2 \%$, $\mathrm{w} / \mathrm{v})$. SD $\Delta \mathrm{N}$ was equivalent to $\mathrm{SD}$ except that ammonium sulfate was left out, while SS was equivalent to SD except that $2 \%(\mathrm{w} / \mathrm{v})$ sucrose was substituted for the glucose. SS $\Delta \mathrm{N}$ was equivalent to $S S$ except that ammonium sulfate was left out. Adenine ( $12 \mathrm{mg}^{-1}$ final concentration) and uridine $\left(40 \mathrm{mg} \mathrm{l}^{-1}\right.$ ) were added to supplement auxotrophies. To test the effects of different drugs on mating, the drugs were added to the SD or $\mathrm{SS} \Delta \mathrm{N}$ agar media. The medium used for selecting specifically for growth of JEC43 cells was SD agar plus 5-FOA (5fluoroorotic acid, $0.05 \%, \mathrm{w} / \mathrm{v})$ and uracil $(0.005 \%, \mathrm{w} / \mathrm{v})$. Because 5-FOA can be converted by the uridine synthesis pathway into 5-fluoro-UMP, which is toxic to cells (Boeke et al., 1984), cells with a functional uridine synthesis pathway are unable to survive on the selective medium. Thus, JEC61 cells (URA5), and the product of JEC61 cells mated with JEC43, were unable to survive on this medium, while JEC43 cells, which carried a mutant ura5 gene, were able to grow and form colonies on the selective medium.

Mating assay. The mating frequency of JEC43 cells was inferred by measuring the number of unmated cells from a mating mixture. The number of unmated JEC43 cells in the mixed population was specifically followed by virtue of their ability to form colonies on the selective medium containing 5 FOA, while neither unmated partner nor mated cells were able to do so. The two strains to be mated (JEC43 and JEC61) were first grown separately in liquid SD medium to a density of about $1 \cdot 2-3 \times 10^{7}$ cells $\mathrm{ml}^{-1}$. The two strains were mixed and plated on mating medium. The mating test, the positive control and the negative control were all spotted onto the same Petri dish to ensure identical conditions. Each spot in the mating-test section contained $10^{3}$ JEC43 cells and $10^{4}$ JEC61 cells (except where indicated otherwise). In the positivecontrol section, each spot contained $10^{3} \mathrm{JEC} 43$ cells, while in the negative-control section, each spot contained $10^{4}$ JEC61 cells. The Petri dish was then incubated at $30^{\circ} \mathrm{C}$ (unless indicated otherwise). At various times after the initiation of mating, cells were transferred from the mating medium to the selective medium (containing 5-FOA) to select for haploid (i.e. unmated) JEC43 cells. Typically, four time points were selected for each mating assay. At each time point, triplicate samples from the positive-control and mating sections and one sample from the negative-control section were independently treated as follows. For each sample, the entire spot was cut out of the agar medium, placed in $1.5 \mathrm{ml}$ water, washed into the liquid by vigorous vortexing, diluted and an aliquot transferred onto 5-FOA-agar selective medium. The 5-FOA-agar Petri dishes were incubated at $30{ }^{\circ} \mathrm{C}$ for $3 \mathrm{~d}$ to allow formation of JEC43 colonies. The total numbers of haploid JEC43 cells present in the mating and control spots were calculated (the mean of triplicate samples) from the number of colonies formed on the 5-FOA plates. From each mating assay, viable colonies were obtained from the positive controls and from the mating tests, while no colonies were ever produced by the negative controls (JEC61 only). The total cell counts for the positive controls and mating tests were plotted against incubation time to generate growth curves. $R$ values for all curves were $>0 \cdot 9$. Rate constants $\left(k_{1}\right.$ and $\left.k_{2}\right)$ were calculated for the control and mating curves. The generation time $(T)$ and the mating frequency ( $\%$ mating) were calculated from the rate constants (see below).

Quantification of mating frequency. C. neoformans JEC43 cells exhibit exponential growth under non-mating conditions. This study has shown that under mating conditions (JEC43 in the presence of excess JEC61), the number of unmated JEC43 cells also increased exponentially, but at a significantly reduced rate compared to nonmating cells. The following formula was used to describe the exponential increase of cell number: $N=N_{0} \mathrm{e}^{k t}$, where $N$ is the cell number, $N_{0}$ is the starting cell number, $k$ is the rate constant and $t$ is the incubation time.

The mating frequency (or \% mating) was defined as the percentage of JEC43 cells which were not recovered as vegetatively growing, colony-forming units during one generation time (defined by the positive control).

If the rate constants in the absence and presence of the opposite mating type are $k_{1}$ and $k_{2}$, respectively, the generation time $(T)$ and the mating rate can be calculated as follows: $T$ $=\ln 2 / k_{1} ; \%$ mating $=1-2^{\left(k_{2} / k_{1}\right)-1}$. Mating at $100 \%$ would occur as $k_{2}$ approaches a limit of negative infinity. A curve with such a rate constant declines dramatically and would result as the number of recovered $\alpha$ cells decreases to zero over time. The mean values for mating rate and generation times are given in the text and tables, with the $\pm 95 \%$ confidence values.

\section{RESULTS}

\section{Initiation of mating}

In preliminary mating experiments, microscopic observations suggested that not all cells mated in a mixed population of $C$. neoformans a plus $\alpha$ mating types. Unlike mating in S. cerevisiae, where up to $100 \%$ of test 

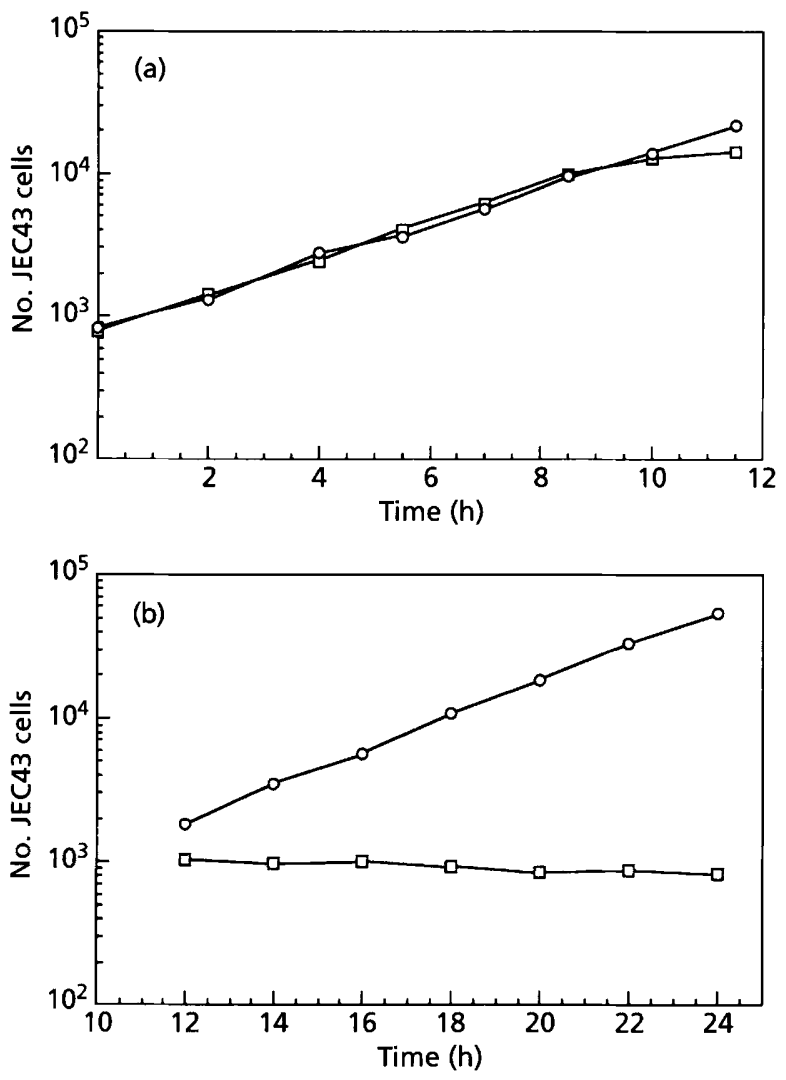

Fig. 1. Inhibition of $\alpha$ cells grown in the presence of a cells. Aliquots of $10^{3} \mathrm{JEC} 43$ cells were incubated in the presence ( $\square$ ) or absence $(\mathrm{O})$ of $10^{4} \mathrm{JEC} 61$ cells on SS $\Delta \mathrm{N}$ agar mating medium (plus adenine and uridine) and incubated at $30^{\circ} \mathrm{C}$. Samples were taken and plated on selective 5-FOA-containing medium as described in Methods. The numbers of JEC43 colonies growing on the selective plates were counted and used to calculate the number of viable haploid JEC43 cells present in the mating mix. Two mating assays were performed and monitored over the $0-12 \mathrm{~h}$ (a) and $10-25 \mathrm{~h}$ (b) periods. The various growth rates from Figs 1 and 2, along with three additional repetitions per growth curve, were compiled into the values given in Tables 1 and 2, where statistical analyses of their reproducibility are given.

cells can mate during a $6-8 \mathrm{~h}$ incubation, a substantial proportion of cryptococcal cells remained as unmated haploid cells, even after prolonged incubation. Therefore, the mating of cryptococcal cells was examined over time to gain insight into the dynamics of the mating process.

JEC43 cells ( $\alpha$ mating type) were challenged to mate by exposure to a 10-fold excess of JEC61 cells (a mating type), on the assumption that this would ensure that every JEC43 cell would be exposed to a potential mating partner. Thus, in these mating experiments, the mating ability of the JEC43 cells was being monitored. JEC43 and JEC61 cells were mixed and plated on SS $\Delta \mathrm{N}$ medium at $30^{\circ} \mathrm{C}$. This mating mix was sampled at various times between 0 and $12 \mathrm{~h}$ (Fig. 1). The positive control (JEC43 cells only), incubated under identical conditions, was also sampled. During the first $8-9 \mathrm{~h}$ of incubation,

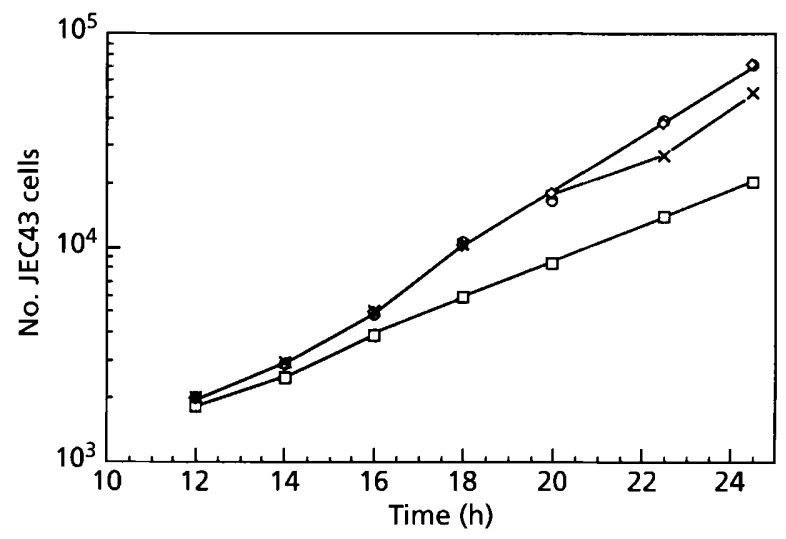

Fig. 2. Growth inhibition of $\alpha$ cells is mating type dependent. Aliquots of $10^{3} \mathrm{JEC} 43$ cells were incubated alone (positive control: $O, \diamond)$ or in the presence of $10^{4}$ JEC61 cells $(\square)$ or $10^{4}$ JEC50 cells $(X)$ on SD agar mating medium (plus adenine and uridine) and incubated at $30^{\circ} \mathrm{C}$. All other conditions were as described in Fig. 1.

JEC43 cells incubated both alone and in the mating population increased exponentially at the same rate. However, at subsequent times, the number of JEC43 cells recovered from the mating mixture was significantly lower than the positive control. After roughly $12 \mathrm{~h}$, the number of recoverable JEC43 cells from the mating mixture remained constant, while cells incubated alone continued their exponential increase. Thus, the presence of cells of the opposite mating type reduced the numbers of recoverable haploid JEC43 cells over time (i.e. reduced its growth rate).

The growth-inhibitory effects were mating type dependent. JEC43 cells were mixed with a 10 -fold excess of either JEC50 or JEC61 cells and incubated on SD-agar medium at $30^{\circ} \mathrm{C}$. Since JEC50 ( $\alpha$ mating type) is genetically identical to JEC61 except for the mating type, it was used to distinguish the effects of mating signals from those caused by other factors. The number of JEC43 cells incubated both alone and in the presence of a 10-fold excess of JEC50 cells increased exponentially at the same rate between 12 and $20 \mathrm{~h}$ (Fig. 2), at which time the rate of increase became slightly smaller in the mixed population. This slight decrease in the rate of growth was attributed to insufficient nutrients, due to their consumption by the greater than 10-fold excess of JEC50 cells. It was assumed that this would also occur when JEC43 cells were co-cultured with a large excess of JEC61 cells. To avoid this nutrient effect, all time points for calculating mating frequencies were selected prior to $20 \mathrm{~h}$ of incubation.

The number of unmated JEC43 cells in the presence of a 10-fold excess of JEC61 cells also increased exponentially, but at a lower rate than that of JEC43 incubated alone or in the presence of JEC50, during the entire period assayed (Fig 2). The difference in the rates between populations containing JEC50 versus JEC61 was presumed to be due to mating signals. The fact that the rate constant for the growth of the mating popu- 
lation was constant and always lower than that of the nonmating population suggested that the rate of mating was also constant during this period of time.

Reduced growth rates correlated with the appearance of hyphae. Pairs of cells consisting of one a and one $\alpha$ mating type were brought together by micromanipulation on SS $\Delta \mathrm{N}$ medium and incubated at $30^{\circ} \mathrm{C}$. These cells were examined microscopically over time. Both cells in a pair divided and after $6 \mathrm{~h}$ incubation, typically 10 haploid (unmated) cells could be counted. At subsequent observations, both hyphae and single, unmated cells were visible; however, it was not possible to count them accurately. Visual inspections of mating populations indicated that more and more hyphae developed over time. These mating populations subsequently grew into colonies, indicating that some unmated haploid JEC43 cells continued vegetative growth in the presence of the opposite mating type, even while other JEC43 cells mated.

\section{Mating kinetics}

Cryptococcal mating was examined in more detail during the 10-24 h period after mixing of partners. JEC43 cells were challenged to mate with a 10 -fold excess of JEC61 cells on SS $\Delta \mathrm{N}$ medium at $30^{\circ} \mathrm{C}$. The curves for the mating population and the positive control (JEC43 alone) between 12 and $24 \mathrm{~h}$ are shown in Fig. 1(b). While the number of JEC43 cells alone increased exponentially during this period, the number of unmated JEC43 cells in the mating population actually decreased very slightly. This corresponds to a mating frequency slightly higher than $50 \%$ (see below). Microscopic examination of mating populations revealed the presence of both single (unmated) cells and hyphae (mated cells). Later experiments (data presented in Tables 1 and 2 ) in which the mating conditions were varied, produced curves that either increased over time (corresponding to mating frequencies of less than $50 \%$ ) or decreased (corresponding to mating frequencies greater than $50 \%)$.

\section{Quantification of the mating frequency}

The rate constants for the curves shown in Fig. 2 were determined and used to quantify the mating frequency of JEC43 cells. Using the formulae presented in Methods, a mating frequency of $23 \%$ was calculated. For all subsequent mating experiments, growth curves such as those shown in Figs 1(b) and 2 were generated and used to determine the mating frequencies shown in Tables 1 and 2.

\section{Optimization of mating-cell ratios}

One of the key points in the mating assay was to guarantee that the test cells had a high probability of contact with a mating partner. This was done by providing a large number of mating partners. However, the results presented above also demonstrated the need to keep the number of mating-partner cells to a minimum, to avoid nutrient limitation. Various partner
Table 1. Effects of nutrients and temperature on mating

\begin{tabular}{|c|c|c|c|}
\hline Medium* & $\begin{array}{c}\text { Temp. } \\
\left({ }^{\circ} \mathrm{C}\right)\end{array}$ & $\%$ Mating $\dagger$ & $\begin{array}{c}\text { Generation } \\
\text { time }(\mathrm{h}) \neq\end{array}$ \\
\hline SD & 30 & $23.5(1.4)$ & $2.5(0.03)$ \\
\hline SS & 30 & $31 \cdot 3(3 \cdot 7)$ & $2.4(0.09)$ \\
\hline $\mathrm{SD} \Delta \mathrm{N}$ & 30 & $45 \cdot 7(1 \cdot 5)$ & $2.3(0.03)$ \\
\hline$S S \Delta N$ & 30 & $53.4(1.4)$ & $2 \cdot 4(0.18)$ \\
\hline SD & 25 & $13 \cdot 2(2 \cdot 9)$ & $3.0(0.16)$ \\
\hline SD & 30 & $23.5(1.4)$ & $2.5(0.03)$ \\
\hline SD & 34 & $3 \cdot 9(4 \cdot 0)$ & $2 \cdot 3(0 \cdot 10)$ \\
\hline SD & 37 & $-4.0(1.6)$ & $2.5(0.09)$ \\
\hline $\mathrm{SS} \Delta \mathrm{N}$ & 25 & $31.7(1.7)$ & $3.6(0.16)$ \\
\hline $\mathrm{SS} \Delta \mathrm{N}$ & 30 & $53.4(1.4)$ & $2 \cdot 4(0 \cdot 18)$ \\
\hline $\mathrm{SS} \Delta \mathrm{N}$ & 34 & $36.7(1.9)$ & $2.8(0.05)$ \\
\hline $\mathrm{SS} \Delta \mathrm{N}$ & 37 & $-1 \cdot 1(3 \cdot 1)$ & $3.5(0.11)$ \\
\hline
\end{tabular}

* SD and SS $\Delta \mathrm{N}$ were supplemented with adenine and uridine. $\dagger \%$ Mating was calculated as described in Methods; $\pm 95 \%$ confidence values are shown in parentheses. Significant differences in mating at the $95 \%$ confidence level occurred between all conditions tested within each grouping except $\mathrm{SD}$ at $34^{\circ} \mathrm{C}$ and $37^{\circ} \mathrm{C}$. One hundred percent mating would occur when all $\alpha$ cells mated with an a cell, resulting in no recovery of $\alpha$ cells on the selective plate.

$¥$ The generation times for JEC43 cells incubated alone on the indicated agar media (the positive control for each mating assay) were calculated by plotting the number of cells recovered (determined by the number of colony forming units) versus time (see Figs 1 and 2 for representative curves). The generation (or doubling) times were calculated from these curves by standard methods. The generation times calculated by this method were about the same as those determined for several liquid cultures tested (data not shown). The standard errors are included in parentheses.

numbers were tested to determine the optimum ratio for quantitative mating. A fixed number of JEC 43 cells $\left(10^{3}\right)$ were mated on SS $\triangle \mathrm{N}$ medium with a 1-, 10-, 20-, or 40fold excess of JEC61 cells. The JEC43 mating frequencies were approximately $20 \%, 53 \%, 53 \%$ and $52 \%$, in the presence of $1-, 10-, 20$ - and 40 -fold excesses of the mating partner, respectively. Furthermore, when JEC43 was incubated with a 40 -fold excess of JEC61, the cell population became saturated quickly, limiting the time when an accurate measurement of mating could be made. Therefore, all subsequent experiments were performed with a 10-fold excess of mating-partner cells.

\section{Effects of nutrients on mating}

When JEC43 and JEC61 cells were co-cultured on SD medium at $30^{\circ} \mathrm{C}$, the mating rate of JEC43 was relatively low $(23.5 \%$ ) (Table 1$)$. In contrast, when cells were cultured on $\mathrm{SS} \Delta \mathrm{N}$ medium (equivalent to $\mathrm{SD}$ except that ammonium sulfate was eliminated and sucrose replaced glucose), the mating rate increased to $53.3 \%$ (Table 1), showing that a nutrient-poor medium stimulated mating. To study the effects of nitrogen and carbon sources separately, mating was measured on two 
Table 2. Effects of CAMP, 8-Br-cAMP and forskolin on mating

The $\%$ mating and generation times $( \pm 95 \%$ confidence values) were determined as described in Table 1. Significant differences in mating at the $95 \%$ confidence level between SS $\Delta \mathrm{N}$ with and without drugs were apparent in all cases tested; such differences occurred on SD medium only with cAMP and 8-Br-cAMP at $300 \mu \mathrm{M}$ or higher.

\begin{tabular}{|c|c|c|c|c|}
\hline Medium* & Drug & $\begin{array}{l}\text { Drug } \\
\text { concn }\end{array}$ & $\%$ Mating & $\begin{array}{c}\text { Generation } \\
\text { time }(h)\end{array}$ \\
\hline$S S \Delta N$ & - & - & $53.4(1.4)$ & $2 \cdot 4(0 \cdot 18)$ \\
\hline $\mathrm{SS} \triangle \mathrm{N}$ & cAMP & $100 \mu \mathrm{M}$ & $60 \cdot 6(2 \cdot 0)$ & $2.5(0.04)$ \\
\hline$S S \Delta N$ & cAMP & $200 \mu \mathrm{M}$ & $65 \cdot 2(4 \cdot 0)$ & $2 \cdot 3(0 \cdot 14)$ \\
\hline $\mathrm{SS} \Delta \mathrm{N}$ & cAMP & $300 \mu \mathrm{M}$ & $63 \cdot 0(2 \cdot 6)$ & $2.4(0.49)$ \\
\hline $\mathrm{SS} \Delta \mathrm{N}$ & 8-Br-cAMP & $100 \mu \mathrm{M}$ & $63.7(1.4)$ & $2 \cdot 3(0 \cdot 10)$ \\
\hline $\mathrm{SS} \Delta \mathrm{N}$ & 8-Br-cAMP & $200 \mu \mathrm{M}$ & $65 \cdot 4(2 \cdot 3)$ & $2.5(0.20)$ \\
\hline $\mathrm{SS} \Delta \mathrm{N}$ & 8-Br-cAMP & $300 \mu \mathrm{M}$ & $64 \cdot 3(1 \cdot 6)$ & $2.4(0.09)$ \\
\hline $\mathrm{SS} \triangle \mathrm{N}$ & Forskolin $†$ & $0 \mu \mathrm{g} \mathrm{ml}^{-1}$ & $52 \cdot 6(0 \cdot 7)$ & $2.4(0.09)$ \\
\hline $\mathrm{SS} \Delta \mathrm{N}$ & Forskolin $\uparrow$ & $1 \mu \mathrm{g} \mathrm{ml}^{-1}$ & $59 \cdot 2(0 \cdot 9)$ & $2.4(0.09)$ \\
\hline $\mathrm{SS} \Delta \mathrm{N}$ & Forskolint & $2 \mu \mathrm{g} \mathrm{ml}^{-1}$ & $58 \cdot 1(0 \cdot 3)$ & $2.6(0.08)$ \\
\hline SD & - & - & $23.5(1.4)$ & $2.5(0.03)$ \\
\hline SD & cAMP & $100 \mu \mathrm{M}$ & $23 \cdot 8(2 \cdot 3)$ & $2.6(0.27)$ \\
\hline $\mathrm{SD}$ & cAMP & $200 \mu \mathrm{M}$ & $23 \cdot 7(0 \cdot 9)$ & $2 \cdot 5(0 \cdot 19)$ \\
\hline $\mathrm{SD}$ & cAMP & $300 \mu \mathrm{M}$ & $36 \cdot 3(0 \cdot 8)$ & $2 \cdot 3(0.23)$ \\
\hline SD & cAMP & $500 \mu \mathrm{M}$ & $32 \cdot 3(0 \cdot 8)$ & $2 \cdot 4(0 \cdot 10)$ \\
\hline SD & 8-Br-cAMP & $100 \mu \mathrm{M}$ & $23 \cdot 5(1 \cdot 1)$ & $2 \cdot 4(0.04)$ \\
\hline $\mathrm{SD}$ & 8-Br-cAMP & $200 \mu \mathrm{M}$ & $21.5(1.0)$ & $2.4(0.06)$ \\
\hline SD & 8-Br-cAMP & $300 \mu \mathrm{M}$ & $33.4(1.8)$ & $2 \cdot 3(0 \cdot 18)$ \\
\hline $\mathrm{SD}$ & 8-Br-cAMP & $500 \mu \mathrm{M}$ & $33 \cdot 1(1 \cdot 8)$ & $2 \cdot 4(0 \cdot 11)$ \\
\hline SD & Forskolint & $0 \mu \mathrm{g} \mathrm{ml}^{-1}$ & $23.8(0.9)$ & $2 \cdot 5(0 \cdot 08)$ \\
\hline $\mathrm{SD}$ & Forskolin† & $1 \mu \mathrm{g} \mathrm{ml}^{-1}$ & $24 \cdot 6(1 \cdot 7)$ & $2 \cdot 5(0 \cdot 18)$ \\
\hline $\mathrm{SD}$ & Forskolinf & $2 \mu \mathrm{g} \mathrm{ml}^{-1}$ & $26 \cdot 6(2 \cdot 0)$ & $2.5(0.08)$ \\
\hline
\end{tabular}

"SD and SS $\Delta \mathrm{N}$ were supplemented with adenine and uridine.

†Cells were treated with forskolin in DMSO. The $0 \mu \mathrm{g} \mathrm{ml}^{-1}$ matings were treated with DMSO only, as a control.

other media, SS and SD $\Delta \mathrm{N}$. The mating frequency of JEC43 cells with JEC61 on SS medium, which was identical to SD except that $2 \%$ sucrose substituted for glucose, increased to $31 \cdot 3 \%$. Mating on SD $\Delta \mathrm{N}$, which was identical to SD except that ammonium sulfate was omitted, gave a mating frequency of $45 \cdot 7 \%$. Thus, both the nitrogen and carbon sources present in the mating medium affected mating.

\section{Effects of temperature on mating}

The mating frequencies of JEC43 with JEC61 were measured on both SD and SS $\Delta \mathrm{N}$ media incubated at $25^{\circ} \mathrm{C}, 30^{\circ} \mathrm{C}, 34^{\circ} \mathrm{C}$ and $37^{\circ} \mathrm{C}$. The highest mating rate resulted at $30^{\circ} \mathrm{C}$, on both SD and SS $\Delta \mathrm{N}$ media (Table 1). The mating frequencies on both SD and SS $\Delta \mathrm{N}$ decreased at both $25^{\circ} \mathrm{C}$ and $34^{\circ} \mathrm{C}$ and were approximately zero at $37^{\circ} \mathrm{C}$.

\section{Effects of various drugs on mating}

Because of the identification of a gene encoding a Gprotein $\alpha$ subunit in C. neoformans, and a potential role in mating (Tolkacheva et al., 1994), several drugs that are known to affect either G-proteins or their effectors were tested for effects on cryptococcal mating.

Aluminium fluoride activates G-proteins by binding to the $G \alpha$ subunit bound to GDP and mimicking a $\gamma$ phosphate (Bigay et al., 1985; Sondek et al., 1994; Sternweis \& Gilman, 1982). JEC43 cells were mated with JEC61 cells on SD mating medium containing various concentrations of aluminium fluoride. The mating frequency increased from $23.5 \%( \pm 1.0)$ to $35.0 \%( \pm 3 \cdot 3)$ with 0 and $5 \mu \mathrm{M} \mathrm{AlF}_{3}$, respectively. The highest mating rate, $41.3 \%,( \pm 2.3)$, occurred with $25 \mu \mathrm{M} \mathrm{AlF}$, and decreased slightly in the presence of $50 \mu \mathrm{M} \mathrm{AlF}{ }_{3}$, to $35.5 \%( \pm 2 \cdot 8)$. Addition of 25 and $50 \mu \mathrm{M}$ $\mathrm{AlF}_{3}$ increased the doubling time of JEC43 from $2.5 \mathrm{~h}$ $( \pm 0.1)$ without $\mathrm{AlF}_{3}$ to $3.2( \pm 0.4)$ and $4.2 \mathrm{~h}( \pm 0.5)$, respectively.

The intracellular concentration of the second messenger cAMP is often regulated by G-proteins, and is the target of many signal transduction pathways. Mating of JEC43 with JEC61 was measured on SD and SS $\Delta \mathrm{N}$ mating media in the presence of various concentrations of cAMP and 8-Br-cAMP (a nonhydrolysable cAMP ana- 
logue), as well as forskolin, an activator of adenylate cyclase (Table 2). Treatment with $100 \mu \mathrm{M}$ cAMP, $100 \mu \mathrm{M} 8$-Br-cAMP or $1 \mu \mathrm{g} \mathrm{ml}^{-1}$ forskolin resulted in an increase in the mating rate on $S S \Delta N$ medium, while on SD medium, higher concentrations $(300 \mu \mathrm{M})$ of cAMP and 8-Br-cAMP were needed.

Caffeine is known to increase intracellular cAMP levels as well as cytoplasmic $\mathrm{Ca}^{2+}$ concentrations. Addition of even a low concentration of caffeine $(0.5 \mathrm{mM})$ increased the cell mating rate on SS $\Delta \mathrm{N}$ medium from $53.4 \%$ $( \pm 1.4)$ to $65.1 \%( \pm 0.9)$. Mating rates in the presence of higher caffeine concentrations (up to $2.0 \mathrm{mM}$ ) remained around $65 \%$. In contrast, addition of up to $2.0 \mathrm{mM}$ caffeine did not have dramatic effects on the mating rate when cells were cultured on SD medium $(23.5 \% \pm 1.4$ versus $25 \cdot 9 \% \pm 2 \cdot 2$ with 0 and $2 \mathrm{mM}$ caffeine, respectively). On SD medium, moderate caffeine treatment $(1.5 \mathrm{mM})$ increased the generation time from $2.5( \pm 0.03)$ to $3.7 \mathrm{~h}( \pm 0.15)$, while a higher caffeine level $(2 \mathrm{mM})$ was required to increase the generation time from 2.4 $( \pm 0.18)$ to $3.6 \mathrm{~h}( \pm 0.26)$ on $\mathrm{SS} \Delta \mathrm{N}$ medium. Importantly, the decrease in growth rate caused by caffeine did not correlate with a change in mating rate on either medium.

\section{DISCUSSION}

A novel quantitative assay was developed to measure mating in C. neoformans, an important pathogenic fungus that causes a lethal meningitis in immunocompromised individuals. One of the factors associated with cryptococcal virulence is the mating type. The $\alpha$ mating type can mate with the second haploid cell type, the a mating type, to form multicellular dikaryotic hyphae. Microscopic analysis of mixed cultures containing $\alpha$ and a cells (mating mixtures) revealed the presence of both dividing haploid (unmated) cells and hyphae (mated cells). Although not quantitative, visual inspection of the mating mixtures suggested that the abundance of both haploid cells and hyphae inceased over time. An assay was developed that allowed precise quantification of the number of haploid, unmated $\alpha$ cells in a mating mixture over time. Using this assay it was shown that co-culturing cells of the $\alpha$ mating type with excess cells of the a mating type reduced the growth rate of the $\alpha$ cells, compared with culturing $\alpha$ cells alone. The onset of growth inhibition correlated with the appearance of hyphae.

The reduced growth rate of JEC43 ( $\alpha$ mating type) when co-cultured with JEC61 (a mating type) was a function of mating type. When the strain JEC50 ( $\alpha$ mating type) was substituted for JEC61 in mating assays, no growth inhibition of JEC43 occurred at early time points, ruling out all effects except those contributed by the matingtype locus of JEC61. Mating-type loci are known to control transmission of growth and developmental signals between different cell types, but in Cryptococcus, mating type is also associated with virulence. Thus, it might be imagined that the a mating-type locus controls secretion of a general growth inhibitor that contributes to virulence in humans and inhibition of growth of
JEC43 cells. However, $\alpha$ mating type cells are more virulent and much more abundant in the environment than a mating type cells (Ellis \& Pfeiffer 1992; KwonChung et al., 1992; Levitz 1991) ; yet in the experiments presented here, a mating type cells inhibited the growth of $\alpha$ mating type cells. This inconsistency, coupled with visual observations correlating the appearance of hyphae with the onset of growth inhibition, provides strength to the only other possible interpretation, adhered to herein, that mating is the event being measured in the assay. The quantitative mating assay allowed the calculation of the percentage mating of JEC43 cells and the identification of several factors affecting this mating response.

The efficiency of mating is temperature dependent. The cryptococcal mating frequency was highest when cells were incubated at $30{ }^{\circ} \mathrm{C}$ and decreased significantly at lower $\left(25^{\circ} \mathrm{C}\right)$ or higher $\left(34^{\circ} \mathrm{C}\right)$ temperatures. Importantly, mating was virtually nonexistent at $37^{\circ} \mathrm{C}$ on both rich and starvation media. This result suggests that, although the mating type itself is associated with virulence, the ability to mate can not be, since mating does not occur at body temperature.

The mating frequency is also dependent on the composition of the medium. Four media, with different nitrogen and carbon sources, were tested for their ability to support mating. The mating frequency was lowest $(\sim 24 \%)$ in a synthetic basal medium, SD, that contained $2 \%$ glucose and $0.4 \%$ ammonium sulfate and increased slightly (to $\sim 31 \%$ ) when $2 \%$ sucrose was substituted for glucose. The mating frequency increased to a yet higher level $(\sim 46 \%)$ when the ammonium sulfate was removed but glucose remained. Finally, mating was highest $(\sim 53 \%)$ when both ammonium sulfate was removed and sucrose substituted for glucose ( $\mathrm{SS} \Delta \mathrm{N}$ medium). The increased mating frequencies resulting from the removal of ammonium sulfate and substituting sucrose were additive, suggesting that their effects are independent. Thus, both the carbon and nitrogen sources influence mating frequency in C. neoformans.

The second messenger cAMP stimulates mating in $C$. neoformans. Cells were exposed to cAMP, 8-Br-cAMP, or forskolin and the mating frequencies determined. On both SD and SS $\Delta \mathrm{N}$ media supplemented with one of these drugs, mating increased maximally about 12 percentage points above basal levels. 8 -Br-cAMP was slightly more effective than cAMP, as would be expected if it could not be degraded, while forskolin increased mating only moderately. A higher drug concentration was needed to stimulate mating on SD than on SS $\triangle N$, suggesting that the stimulatory effect of cAMP is antagonized by the nutrients present in SD.

Cryptococcal mating can be stimulated by aluminium fluoride. Addition of aluminium fluoride to mating cells on SD medium increased the cell mating rate to $\sim 41 \%$. The addition of similar concentrations of aluminium fluoride to vegetatively growing haploid cultures lengthened the doubling time from 2.5 to $3.2 \mathrm{~h}$. It is 
known that aluminium fluoride can activate heterotrimeric G-proteins and aluminium fluoride induced activations are considered evidence for involvement of G-proteins in a cellular response pathway (Bigay et al., 1985; Sondek et al., 1994; Sternweis \& Gilman, 1982). Thus, the effect of aluminium fluoride on C. neoformans growth and mating is consistent with G-protein involvement.

Caffeine has complicated effects on cryptococcal mating. Among other effects, caffeine is known to inhibit the activities of cAMP phosphodiesterases, thereby increasing intracellular cAMP concentrations. Importantly, caffeine increased cell mating on SS $\Delta \mathrm{N}$ medium, even at a low concentration. Surprisingly, however, caffeine had no obvious effects on mating when cells were cultured on SD medium, showing a strong antagonistic effect of nutrients.

A simple model describing the C. neoformans mating process is as follows. After exposure to mating partners, during each cell cycle, a fraction of the cells initiate mating while the rest of the population continues growth and division to produce progeny. Hence, the number of unmated cells increases exponentially but at a slower rate than the number of haploid cells in the absence of the opposite mating type. The fraction of the single-cell population that mates during each generation is influenced by factors such as nutrients and cAMP. Future experiments will examine the effects of these factors on the length of time spent at the START point in the cell cycle, where yeast cells must be cell-cycle arrested before mating can occur.

\section{ACKNOWLEDGEMENTS}

This work was supported by a grant from the US Public Health Service, NCDDG-OI programme, cooperative agreement U01-AI-31696.

\section{REFERENCES}

Bigay, J., Deterre, P., Pfister, C. \& Chabre, M. (1985). Fluoroaluminates activate transducin-GTP by mimicking the $(\gamma)$-phosphate of GTP in its binding site. FEBS Lett 191, 181-185.

Blumer, K. J. \& Thorner, J. (1991). Receptor G-protein signalling in yeast. Annu Rev Physiol 53, 37-57.

Boeke, J. D., LaCroute, F. \& Fink, G. R. (1984). A positive selection for mutants lacking orotidine- $5^{\prime}$-phosphate decarboxylase activity in yeast : 5-fluoroorotic-acid resistance. Mol Gen Genet 197, 345-346.

Chuck, S. L. \& Sande, M. A. (1989). Infections with Cryptococcus neoformans in the acquired immunodeficiency syndrome. $N$ Engl J Med 321, 794-799.

Ellis, D. H. \& Pfeiffer, T. J. (1992). The ecology of Cryptococcus neoformans. Eur J Epidemiol 8, 321-325.

Kovacs, J. A., Kovacs, A. A., Polis, M. \& 12 other authors (1985). Cryptococcosis in the acquired immunodeficiency syndrome. Ann Intern Med 103, 533-538.

Kurjan, J. (1993). The pheromone response pathway in Saccharomyces cerevisiae. Annu Rev Genet 27, 147-179.
Kwon-Chung, K. J. (1976a). Morphogenesis of Filobasidiella neoformans, the sexual state of Cryptococcus neoformans. Mycologia 68, 821-833.

Kwon-Chung, K. J. (1976b). A new species of Filobasidiella neoformans, the sexual state of Cryptococcus neoformans B and C serotypes. Mycologia 68, 942-946.

Kwon-Chung, K. J. \& Bennett, J. E. (1992). Cryptococcosis. In Medical Mycology, pp. 397-446. Edited by L. A. Febiger. Philadelphia: Lea and Febiger.

Kwon-Chung, K. J., Edman, J. C. \& Wickes, B. L. (1992). Genetic association of mating types and virulence in Cryptococcus neoformans. Infect Immun 60, 602-605.

Levitz, S. M. (1991). The ecology of Cryptococcus neoformans and the epidemiology of cryptococcosis. Rev Infect Dis 13, 1163-1169.

Marsh, L., Neiman, A. M. \& Herskowitz, I. (1991). Signal transduction during pheromone response in yeast. Annu Rev Cell Biol 7, 699-728.

Mitchell, T. G. \& Perfect, J. R. (1995). Cryptococcosis in the era of AIDS - 100 years after the discovery of Cryptococcus neoformans. Clin Microbiol Rev 8, 515-548.

Moore, T. D. E. \& Edman, J. C. (1993). The $\alpha$ mating type locus of Cryptococcus neoformans contains a peptide pheromone gene. Mol Cell Biol 13, 1962-1970.

Nielsen, O. (1993). Signal transduction during mating and meiosis in S. pombe. Trends Cell Biol 3, 60-65.

Rozenbaum, R. \& Rios Goncalves, A. J. (1994). Clinical epidemiological study of 171 cases of cryptococcosis. Clin Infect Dis 18, 369-380.

Sondek, J., Lambright, D. G., Noel, J.P., Hamm, H. E. \& Sigler, P. B. (1994). GTPase mechanism of G-proteins from the $1 \cdot 7-\AA$ crystal structure of transducin $\alpha$-GDP-AlF4. Nature 372, 276-279.

Sprague, G. F., Jr \& Thorner, J. (1992). Pheromone response and signal transduction during the mating process of Saccharomyces cerevisiae. In The Molecular and Cellular Biology of the Yeast Saccharomyces, pp. 657-744. Edited by J. R. P. E. W. Jones \& J. R. Broach. Cold Spring Harbor, NY: Cold Spring Harbor Laboratory.

Stansell, J. D. (1993). Pulmonary fungal infections in HIV-infected persons. Semin Respir Infect 8, 116-123.

Sternweis, P. C. \& Gilman, A. G. (1982). Aluminium: a requirement for activation for the regulatory component of adenylate cyclase by fluoride. Proc Natl Acad Sci USA 79, 4888-4891.

Sugar, A. M. (1991). Overview : cryptococcosis in the patient with AIDS. Mycopathologia 114, 153-157.

Tolkacheva, T., McNamara, P., Piekarz, E. \& Courchesne, W. E. (1994). Cloning of a Cryptococcus neoformans gene, GPA1, encoding a G-protein $\alpha$ subunit homolog. Infect Immun 62, 2849-2856.

Vaillancourt, L. J. \& Raper, C. A. (1996). Pheromones and pheromone receptors as mating-type determinants in basidiomycetes. Genet Eng 18, 219-247.

Zuger, A., Louie, E., Holzman, R. S., Simberkoff, M. S. \& Rahal, J. J. (1986). Cryptococcal disease in patients with the acquired immunodeficiency syndrome: diagnostic features and outcome of treatment. Ann Intern Med 104, 234-240.

Received 17 November 1997; revised 20 January 1998; accepted 27 February 1998. 